\title{
Growth and repair factors, osteoactivin, matrix metalloproteinase and heat shock protein 72, increase with resolution of inflammation in musculotendinous tissues in a rat model of repetitive grasping
}

Nagat Frara', Samir M. Abdelmagid ${ }^{2}$, Michael Tytell ${ }^{3}$, Mamta Amin'1 ${ }^{1}$ Steven N. Popoff', Fayez F. Safadi ${ }^{4}$ and Mary F. Barbe ${ }^{1^{*}}$

\begin{abstract}
Background: Expression of the growth factor osteoactivin $(\mathrm{OA})$ increases during tissue degeneration and regeneration, fracture repair and after denervation-induced disuse atrophy, concomitant with increased matrix metalloproteinases (MMPs). However, OA's expression with repetitive overuse injuries is unknown. The aim of this study was to evaluate: 1) OA expression in an operant rat model of repetitive overuse; 2) expression of MMPs; 3 ) inflammatory cytokines indicative of injury or inflammation; and 4) the inducible form of heat shock protein 70 (HSPA1A/HSP72) as the latter is known to increase during metabolic stress and to be involved in cellular repair. Young adult female rats performed a high repetition negligible force (HRNF) food retrieval task for up to 6 weeks and were compared to control rats.

Methods: Flexor digitorum muscles and tendons were collected from 22 young adult female rats performing a HRNF reaching task for 3 to 6 weeks, and 12 food restricted control (FRC) rats. OA mRNA levels were assessed by quantitative polymerase chain reaction (qPCR). OA, MMP-1, -2, -3, and -13 and HSP72 protein expression was assayed using Western blotting. Immunohistochemistry and image analysis was used to evaluate OA and HSP72 expression. ELISA was performed for HSP72 and inflammatory cytokines.

Results: Flexor digitorum muscles and tendons from 6-week HRNF rats showed increased OA mRNA and protein expression compared to FRC rats. MMP-1, -2 and -3 progressively increased in muscles whereas MMP-1 and -3 increased in tendons with HRNF task performance. HSP72 increased in 6-week HRNF muscles and tendons, compared to controls, and co-localized with OA in the myofiber sarcolemma. IL-1alpha and beta increased transiently in tendons or muscles in HRNF week 3 before resolving in week 6 .
\end{abstract}

Conclusion: The simultaneous increases of OA with factors involved in tissue repair (MMPs and HSP72) supports a role of $O A$ in tissue regeneration after repetitive overuse.

Keywords: Overuse, Osteoactivin, Metalloproteinases, Heat shock protein, Restorative repair, Muscle, Tendon

\footnotetext{
* Correspondence: mbarbe@temple.edu

${ }^{1}$ Department of Anatomy and Cell Biology, Temple University School of

Medicine, Philadelphia, PA, USA

Full list of author information is available at the end of the article
} 


\section{Background}

Overuse injuries are now considered a leading cause of long-term pain and physical disability world-wide [1], with diagnoses including tendinopathies and muscle disorders $[2,3]$. Studies have identified repetition and duration as two of the key risk factors for upper extremity overuse injuries [4]. Moreover, overuse injuries commonly occur as a result of prolonged repetitive loading of the muscletendon unit, even at low force levels $[5,6]$.

Several studies have shown that repetitive movements lead to tissue injury ([7] and as reviewed in [8]). Barbe and Barr have developed an operant rat model of upper extremity overuse in which rats learn to perform repetitive tasks, such as a high repetition negligible force (HRNF) food retrieval task. In this particular task, rats reach at a rate of 4 reaches/min into a portal to retrieve a $45-\mathrm{mg}$ pellet of food for $2 \mathrm{~h} /$ day (in four $30 \mathrm{~min}$ sessions/day) for 3 days/week. Performance of this HRNF task leads to modest signs of myositis and tendinitis in forearm muscles and tendons and increased focal sites of myotendon fray and fibroblast proliferation $[9,10]$. After such tissue damage, it is known that inflammatory cells infiltrate tissues, which, along with injured cells, produce inflammatory cytokines and other mediators that either exacerbate damage or assist in tissue repair $[11,12]$.

Osteoactivin (OA) is a type I transmembrane protein that is also known as glycoprotein nonmelanoma protein $\mathrm{B}$ (GPNMB). OA is a growth factor involved in tissue turnover during regeneration [13-15] and is known to up-regulate the expression of matrix metalloproteinases (MMPs) in fibroblasts infiltrating denervated muscle, leading to increased extracellular matrix (ECM) turnover [16]. OA increases in tissue matrices during fracture repair [13] and influences adhesion and migration of select cell types (including fibroblasts) that are involved in tissue repair [17], and regulates muscle regeneration in desmin-deficient cardiomyocytes [18]. In a process called ectodomain shedding, the extracellular fragments of $\mathrm{OA}$ are cleaved on the plasma membrane and released to the ECM where they act as cytokines or growth factors [19-21] in addition to increasing MMP production [14]. While it is clear that OA increases under several types of repair and regeneration conditions, its expression in association with overuse injuries has yet to be examined.

The inducible form of HSP70 (HSPA1A; commonly known as HSP72) mediates tissue repair after injury and protects skeletal muscle from atrophy, damage and dystrophy [22-26]. HSP70/72 plays a role in skeletal muscle repair or regeneration and adaptation after high-force eccentric exercise [27-29] and increases concomitant with MMP-2 in skeletal muscle following high intensity training [30], apparently acting together to promote muscle matrix remodeling [31]. Increased expression of HSP70 following muscle injury regulates both the early inflammatory and regenerative phases of muscle regeneration [32].

Our goals here were to evaluate the temporal and spatial expression of OA, MMPs and HSP72 in forelimb flexor digitorum muscles and tendons in rats performing a HRNF task for 3 to 6 weeks. Inflammatory cytokines were also examined in order to determine if injury/inflammatory processes were present in the tissues at the same time points. Although OA has yet to be studied in a model of overuse, we hypothesized that it would increase in the overloaded skeletal muscles and tendons, as would other known mediators of repair (MMPs and HSP70).

\section{Methods}

\section{Animals}

All experiments were approved by the Temple University Institutional Animal Care and Use Committee in compliance with NIH guidelines for the humane care and use of laboratory animals. Rats were housed individually in the central animal facility in transparent plastic cages in a $12 \mathrm{~h}$ light: $12 \mathrm{~h}$ dark cycle with free access to water. Studies were conducted on a total of 34 young adult (3.5 months of age at onset of experiments) Sprague-Dawley, female rats. All rats were handled for 1 week, and then food restricted to 80-90\% of their naïve full body weights for another week before onset of the experiment to motivate interest in $45 \mathrm{mg}$ food pellets used for reward and retrieval (Banana flavored $45 \mathrm{mg}$ food pellets; Bio-Serve, Flemington, NJ). All rats were weighed once to twice per week, provided regular rat chow daily and allowed to gain weight over the course of the experiments since they were young adult rats. All rats were maintained within 5-10\% of the weights of age-matched normal control rats (used only for weight matching purposes and therefore not included in the study). Rats were then randomly divided into food restricted control rats $(n=12)$ and high repetition negligible force (HRNF) task rats $(n=22)$ performing this task for 3 weeks $(n=12)$ and 6 weeks $(n=10)$.

\section{Behavioral task paradigm}

The HRNF task has been described in detail previously [9]. Briefly, rats were trained for $5 \mathrm{~min} /$ day, 5 days/week for 10-12 days to learn to retrieve a $45-\mathrm{mg}$ pellet of food from a shoulder-height portal at a reach rate of 4 reaches/min, making this a high repetition task (i.e. faster than $30 \mathrm{~s} /$ cycle) [33]. After this initial training period, task rats then performed the HRNF task for $2 \mathrm{~h}$ /day in four $30 \mathrm{~min}$ sessions/day on 3 days/week for 3 to 6 weeks in customized operant behavioral apparati (Med Associates, St Albans, VT), described in detail previously [9]. 
Retrieval of the $45 \mathrm{mg}$ food pellet from the portal was estimated as $<5 \%$ maximum pulling force, making this a negligible force task [34]. Rats were allowed to use their preferred reach limb to reach and retrieve the food pellet, hereafter referred to as the reach limb. Tissues used in this study were from the reach limbs.

\section{Quantitative real-time PCR (qPCR)}

Twelve animals were euthanized with an overdose of sodium pentobarbital (120 mg/kg body weight) and forearm flexor muscles were collected the flexor digitorum mass from FRC, and 3- and 6-week HRNF rats $(n=3$ / group). Each muscle belly was divided into two longitudinal parts; half was used for RNA extraction and half for protein extraction. The half for RNA extraction was put into RNAlater RNA Stabilization Reagent (QIAGEN, Valencia, CA) for $2 \mathrm{~h}$ at room temperature and then stored at $-80{ }^{\circ} \mathrm{C}$. Total RNA was isolated using TRIzol reagent (Invitrogen, Carlsbad, CA). The concentration of each RNA sample was determined using a spectrophotometer and the integrity was monitored on $1 \%$ formaldehyde denatured gels. After confirming RNA integrity on an agarose gel, cDNA was prepared from mRNA extracts from the above tissue samples ( $n=3$ /group) using a High Capacity cDNA Reverse Transcription kit (Applied Biosystems ${ }^{\mathrm{TM}}$, Foster City, CA). PCR primer sets for the following were used: OA (Cat\# PPR45879B, SABiosciences, Frederick, MD) and GAPDH (Cat\# PPR51520A, SABiosciences, Frederick, MD). Quantitative real time PCT (qPCR) was then performed in duplicate for $20 \mu \mathrm{l}$ reactions each containing $1 \mu \mathrm{l}$ cDNA reaction mix, $100 \mathrm{nM}$ of each primer and $10 \mu \mathrm{l} 2 \mathrm{x} \mathrm{SYBR}^{\bullet}$ Green PCR Master Mix method (Applied Biosystems ${ }^{\mathrm{TM}}$, Foster City, CA), on an ABI 7500 Fast Real-Time PCR system (Applied Biosystems $\left.{ }^{\mathrm{TM}}\right)$. PCR cycles consisted of an initial cycle of $50{ }^{\circ} \mathrm{C}$ for $2 \mathrm{~min}$ and the second cycle of $95{ }^{\circ} \mathrm{C}$ for $10 \mathrm{~min}$, followed by a two-step program of $95{ }^{\circ} \mathrm{C}$ for $15 \mathrm{~s}$ and $60{ }^{\circ} \mathrm{C}$ for $1 \mathrm{~min}$ for 40 cycles. Using GAPDH as the internal control, relative gene expression among samples was calculated by comparison of $\mathrm{C}_{t}$ (threshold cycle) values. A dissociation curve was checked for each qPCR run to confirm specific amplification of target RNA. The PCR primer set (OA) used was purchased from SABiosciences.

\section{Protein isolation and western blotting}

Animals were euthanized with an overdose of sodium pentobarbital (120 mg/kg body weight) before muscle and tendon collection from the flexor digitorum mass from FRC rats $(n=8)$ and from rats that performed the HRNF task for 3 weeks $(n=4)$ or 6 weeks $(n=6)$. As described above, the muscles were divided into half longitudinally. The half for protein analysis was snap frozen and stored at $-80{ }^{\circ} \mathrm{C}$ until homogenization and preparation for protein analysis using previously described methods $[35,36]$. Total protein was determined using BCA-200 protein assays (Bicinchoninic Acid, Pierce, Rockford, IL). Then, $30 \mu \mathrm{g}$ of protein sample was mixed with 5X Laemmli sample buffer (Bio-Rad, Hercules, CA) mixed with denaturing buffer, $25 \% \beta$ mercaptoethanol, heated to $100{ }^{\circ} \mathrm{C}$ for $5 \mathrm{~min}$, subjected to sodium dodecyl sulfate-polyacrylamide gel electrophoresis (SDS-PAGE) and transferred at $100 \mathrm{~V}$ for $1 \mathrm{~h}$ at $4{ }^{\circ} \mathrm{C}$ to an nitrocellulose membrane (Bio-Rad) using semi-dry transfer apparatus (Bio-Rad). The membranes were blocked with $5 \%$ non-fat milk in Tris-buffered saline (TBS)-0.1 \% Tween-20 (TBST) for $1 \mathrm{~h}$ at room temperature and then incubated with the following primary antibodies: anti-rabbit beta Actin (1:1000; Sigma, St Louis, MO), anti-mouse GAPDH (1:500; Santa Cruz Biotechnology, Delaware Avenue, CA), anti-mouse Hsp72 (1:300; Stressgen, Ann Arbor, MI), anti-rabbit MMP-1 (1:500; Abbiotec, San Diego, CA), anti-mouse MMP-2 (1:200; Abcam, Cambridge, MA), anti-rabbit MMP3 (1:200; Novus Biologicals, Littleton, CO), antimouse MMP-13 (1:200; Abcam), anti-rabbit OA/ GPNMB (1:500; Bioss Inc. Woburn, MA) and custom made anti-chicken OA (1:250), which was produced as previously described in [37], in blocking buffer (same as above) overnight at $4{ }^{\circ} \mathrm{C}$. The blot was then washed with 1X TBS-0.1\% Tween-20 (TBST) and incubated with the following horseradish peroxidase-conjugated secondary antibodies: donkey anti-chicken, anti-mouse or anti-rabbit (1:5000; Jackson Immunoresearch, West Grove, PA), in blocking buffer for $1 \mathrm{~h}$ at room temperature. The blot was washed again with TBST, incubated with SuperSignal West Pico Chemiluminescent Substrate (Thermo Scientific, Rockford, IL) and exposed to film. Quantification of the bands was performed using either Image J or myImageAnalysis v2.0 software (Thermo Scientific).

\section{ELISA}

For protein analysis, tissues from above animals that had been prepared for protein analysis were used in ELISAs to determine HSP72 and inflammatory cytokine levels. All muscle and tendon samples were homogenized separately with 0.5 to $1.0 \mathrm{ml}$ RIPA buffer $((\mathrm{NaCl}, \mathrm{KCl}$, $\mathrm{NaH}_{2} \mathrm{PO}_{4}, \mathrm{KH}_{2} \mathrm{PO}_{4}$, and $\mathrm{DDH}_{2} \mathrm{O}+\mathrm{NaOH}$ ) plus EDTA free complete protease inhibitor cocktail tablets (Roche Diagnostics, GMPH, Germany) using a PowerGen 125 Homogenizer. Tissue homogenates were centrifuged at $14,000 \mathrm{rpm}$ for $15 \mathrm{~min}$. at $4{ }^{\circ} \mathrm{C}$. Total protein was determined using BCA-200 protein assays (Bicinchoninic Acid). For ELISA, tissue lysates (50 microliter aliquots) were analyzed using a commercially available single-plex ELISA kit for HSP72 (EKS-700, Stressgen, purchased before its purchase by Enzo Life Sciences, Inc, Farmingdale, NY), according to the manufacturers' protocol. 
Tissue lysates were also analyzed for IL-1alpha, IL-1beta, TNF-alpha and IL-10 using commercially available ELISA kits according to manufacturer's protocols (each from BioSource International). Each sample was run in duplicate. Data (ng protein of HSP72 and pg protein for the cytokines) were normalized to $\mu \mathrm{g}$ total protein.

\section{Immunohistochemical analyses and quantification}

Animals received an overdose of sodium pentobarbital (120 mg/kg body weight) before being perfused transcardially with first sterile saline and then $4 \%$ paraformaldehyde in 0.1 M phosphate buffer (pH 7.4): FRC $(n=6)$, 3-week HRNF $(n=6)$ and 6-week HRNF $(n=4)$. Tissues were collected and postfixed "en bloc" by immersion overnight. A proximal portion of the muscle mass was then removed with a scalpel for cross-sectional sectioning while the remaining flexor digitorum muscles and tendons were separated as a flexor mass from the bones for longitudinal sectioning, as previously depicted [38]. All tissues were cryoprotected in $30 \%$ sucrose in phosphate buffered saline (PBS) before frozen-sectioning using a cryostat into $15 \mu \mathrm{m}$ cross sectional or longitudinal slices. Sections were then placed onto charged slides (Fisher, Super Frost Plus) and allowed to dry overnight before storage at $-80^{\circ} \mathrm{C}$.

Sections on slides were treated with $3 \% \mathrm{H}_{2} \mathrm{O}_{2}$ in methanol to block for endogenous peroxidase for $30 \mathrm{~min}$ (if the tissues were to be used for HRP-DAP visualization), washed in PBS, then permeabilized with $0.05 \%$ pepsin in $0.01 \mathrm{~N} \mathrm{HCL}$ prior to blocking with $10 \%$ goat serum in PBS for $20 \mathrm{~min}$ at room temperature. Sections on slides were then probed in batches with the following primary antibodies: antiHSP72 (1:1000, C92F3A-5, Enzo Life Sciences, Inc) or anti-osteoactivin (1:350, custom made anti-chicken OA) produced and verified, as previously described [37]. On the $2^{\text {nd }}$ day after washing, one set of sections from all groups that had been incubated with anti-OA antibody was incubated with goat anti-chicken secondary IgG antibody conjugated to HRP (Jackson Immunoresearch Laboratories, West Grove, PA; diluted 1:100 in PBS, and incubated $2 \mathrm{~h}$ at room temperature before washing in PBS) and visualized using DAB (Fast DAB, Sigma). These sections were counterstained lightly with eosin, then dehydrated and coverslipped with DPX mounting medium for bright field microscopy (for HRP-DAB). A second set of sections was incubated with anti-HSP72 antibody and then with a donkey anti-mouse secondary IgG antibody conjugated to Cy3 (red fluorescent tag) diluted as above (Jackson Immunoresearch Laboratories). A third set of slides was incubated with both anti-OA antibody and anti-HSP72 and then with appropriate secondary antibodies conjugated to $\mathrm{Cy} 2$ (green fluorescent tag) or Cy3 (red fluorescent tag) (Jackson Immunoresearch Laboratories). The fluorescent tag-labeled sections were washed with PBS and coverslipped with $80 \%$ glycerol in PBS for epifluorescence microscopy.

The specificity of the OA and HSP72 antibodies are shown in western blots that are part of this study. In addition, negative control staining was performed by omitting either the primary antibody or the secondary antibody. No labeling was observed as a result of incubation of tissues with serum and then secondary antibodies alone (data not shown). Preabsorption controls were performed to demonstrate if the antibodies bound specifically to the antigen of interest. Specifically, specificity of the OA and HSP72 antibodies was determined via the use of recombinant human Osteoactivin/GPNMB/Fc Chimera (Cat\# 2550-AC, R\&D Systems, Minneapolis, MN) and recombinant human HSP70 protein (Product\# SPP-755, StressGen, Farmingdale, NY; purchased from StressGen before its purchase by Enzo Life Sciences, Inc.), respectively. A ten-fold excess of purified protein was pre-incubated with the matching antibody overnight at $4{ }^{\circ} \mathrm{C}$, the mixture centrifuged and then the preabsorbed antibody supernatant was incubated with the tissues (after pepsin and goat serum treatments) similar to that described above before washing and incubation with secondary antibodies. No labeling was observed in the tissues for either pre-absorbed antibody (data not shown), matching previously published specificity of the custom made OA antibody in bone tissues [37].

The percent area with OA and HSP72 immunostaining in muscles and tendons was quantified from HRP-DAB stained and fluorescent stained slides, respectively. This quantification was performed using an image analysis program (Bioquant Osteo II, Nashville, TN) and previously described thresholded pixel count methods [39]. The person performing the quantification was blinded to group assignment.

\section{Statistical analysis}

Statistical analyses were performed using Prism 4 and 5 (GraphPad Software, La Jolla, CA). Univariate ANOVAs were used to analyze quantitative PCR, Western blot densitometry and ELISA results for differences in analytes between groups. Then, post hoc analyses were carried out using the Bonferroni test for multiple comparisons with FRC used as the control group and adjusted $\mathrm{p}$ values are reported. An adjusted $\mathrm{p}$ value of $<0.05$ was considered significant for all analyses. Data are presented as the mean \pm standard error of the mean (SEM).

\section{Results}

Increased osteoactivin in flexor digitorum muscles with HRNF task

Utilizing quantitative real time PCR (qPCR) analysis, we observed a significant up-regulation of OA gene expression 
in muscles of 6-week HRNF animals $(p<0.01)$ compared to food restricted only control (FRC) rats (Fig. 1a). These findings were confirmed using Western blot analysis, which showed progressive increases in OA protein levels with HRNF task performance compared to FRC rats (Fig. 1b). The $65 \mathrm{kDa}$ and $115 \mathrm{kDa}$ molecular weight bands of OA were increased $(p<0.01)$ while the $47 \mathrm{kDa}$ band was not increased with HRNF task performance (Fig. 1b-d). To further examine the expression of $\mathrm{OA}$ in the muscle tissue of our rat model, we performed immunohistochemistry and subsequent quantification of $\mathrm{OA}$ in the flexor digitorum muscles of HRNF rats. OA immunostaining was increased in 6-week HRNF muscles $(p<0.01)$ compared to controls (Fig. 1e). OA was localized to the sarcolemma and to macrophage-like cells located between individual muscle fibers in 6-week HRNF muscles yet was absent in control muscles (Fig. 1f and g).

\section{MMP-1, $-2,-3$ and -13 are altered in flexor digitorum muscles with HRNF task}

Western blotting detection showed that MMP-1, -2 and -3 were significantly increased in 3 - and 6-week HRNF rat muscles compared to FRC rats (Figs. 2 and 3). Specifically, the $54 \mathrm{kDa}$ molecular weight band of MMP-1 (Fig. 2a and b) and the $66 \mathrm{kDa}$ active form of MMP-2 (Fig. 2c and e) were increased in HRNF rat muscles $(p<$

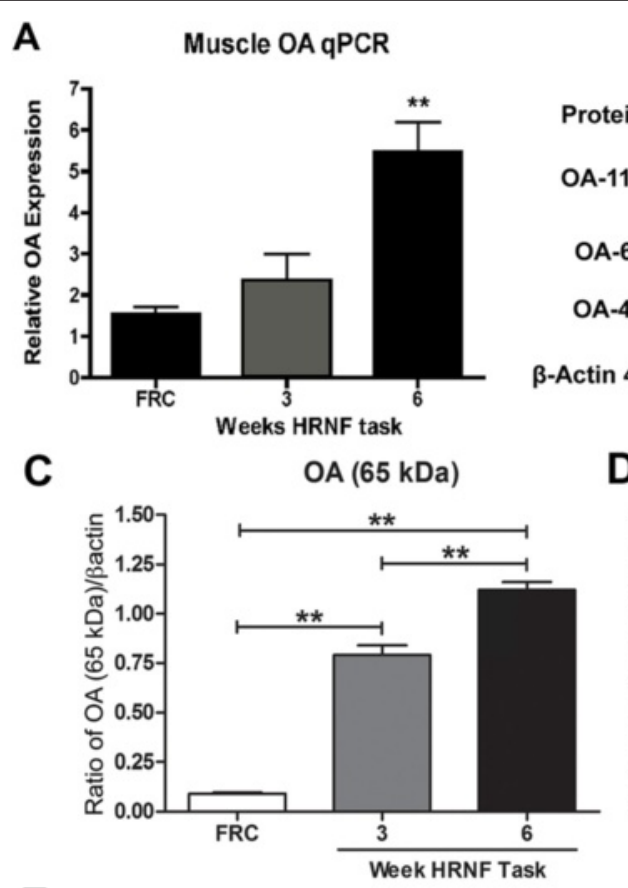

\section{B}

Muscle OA Western Blot

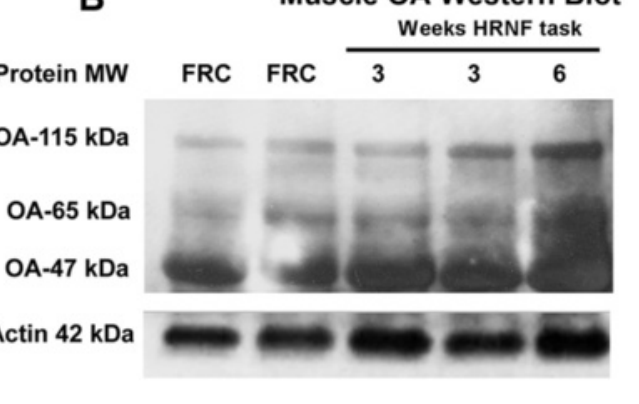

D $\quad \mathrm{OA}(115 \mathrm{kDa})$
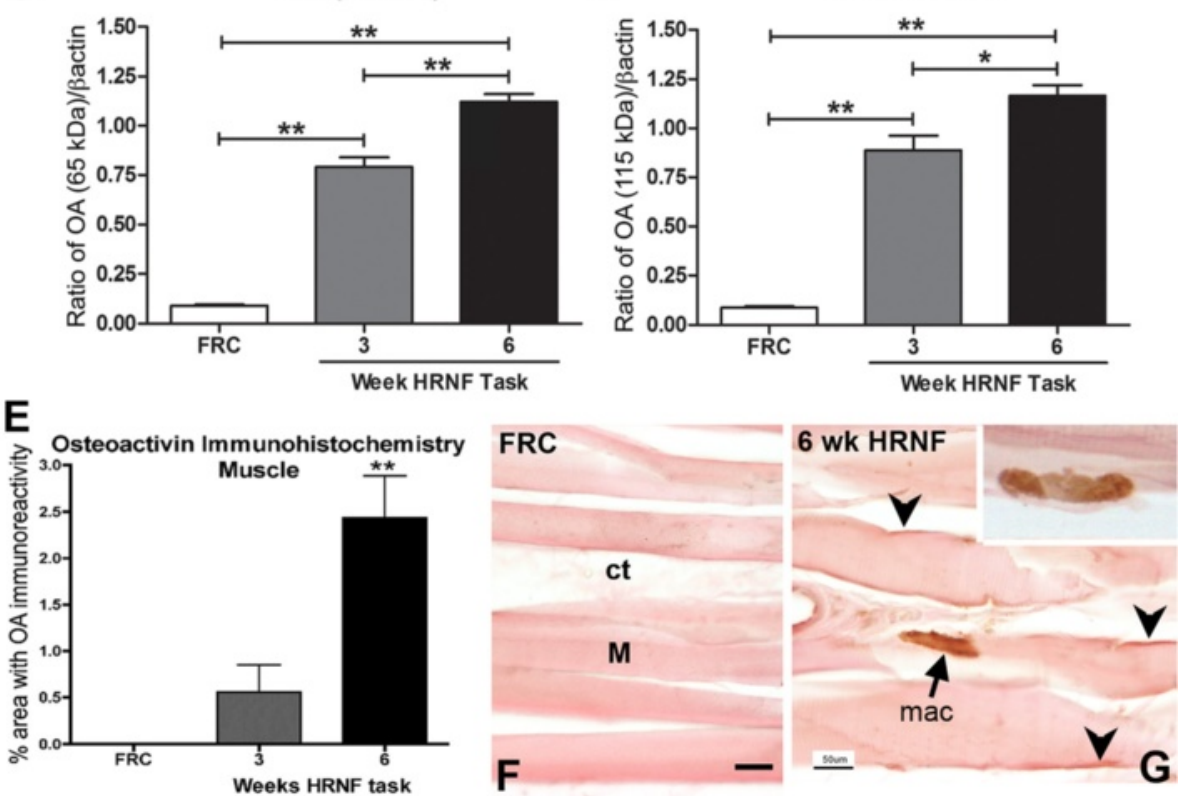

Fig. 1 Osteoactivin (OA) expression increases in flexor digitorum muscles with high repetition negligible force (HRNF) task. a OA mRNA expression levels (determined using quantitative PCR, qPCR) in muscles of food restricted control (FRC) rats and rats that had performed a HRNF food retrieval task for 3 or 6 weeks. Values were normalized to GAPDH mRNA levels. b A representative Western blot of muscle homogenates probed with anti-OA. Bands are at the expected molecular weights of OA in muscle (approximately 115, 65 and $47 \mathrm{kDa}$ ). $\beta$-actin was used as the loading control (at $42 \mathrm{kDa}$ ). c, d Densitometric analysis of two OA bands (65 and $115 \mathrm{kDa}$ ) from three replicate Western blots normalized to $\beta$-actin levels. e Quantification of OApositive immunostaining as a percent of total tissue area. $\mathbf{f}, \mathbf{g}$ Examples of OA immunostaining in longitudinal sections of FRC and HRNF rat muscles showing OA in the myofiber sarcolemma (arrowheads) and macrophages (mac) only in HRNF muscles. $\mathrm{Ct}=$ connective tissue, $\mathrm{M}=$ muscle. ${ }^{*} p<0.05$, ${ }^{* *} p<0.01$, compared to FRC rats. Scale bars in $F$ and $G=50 \mu \mathrm{m}$ 

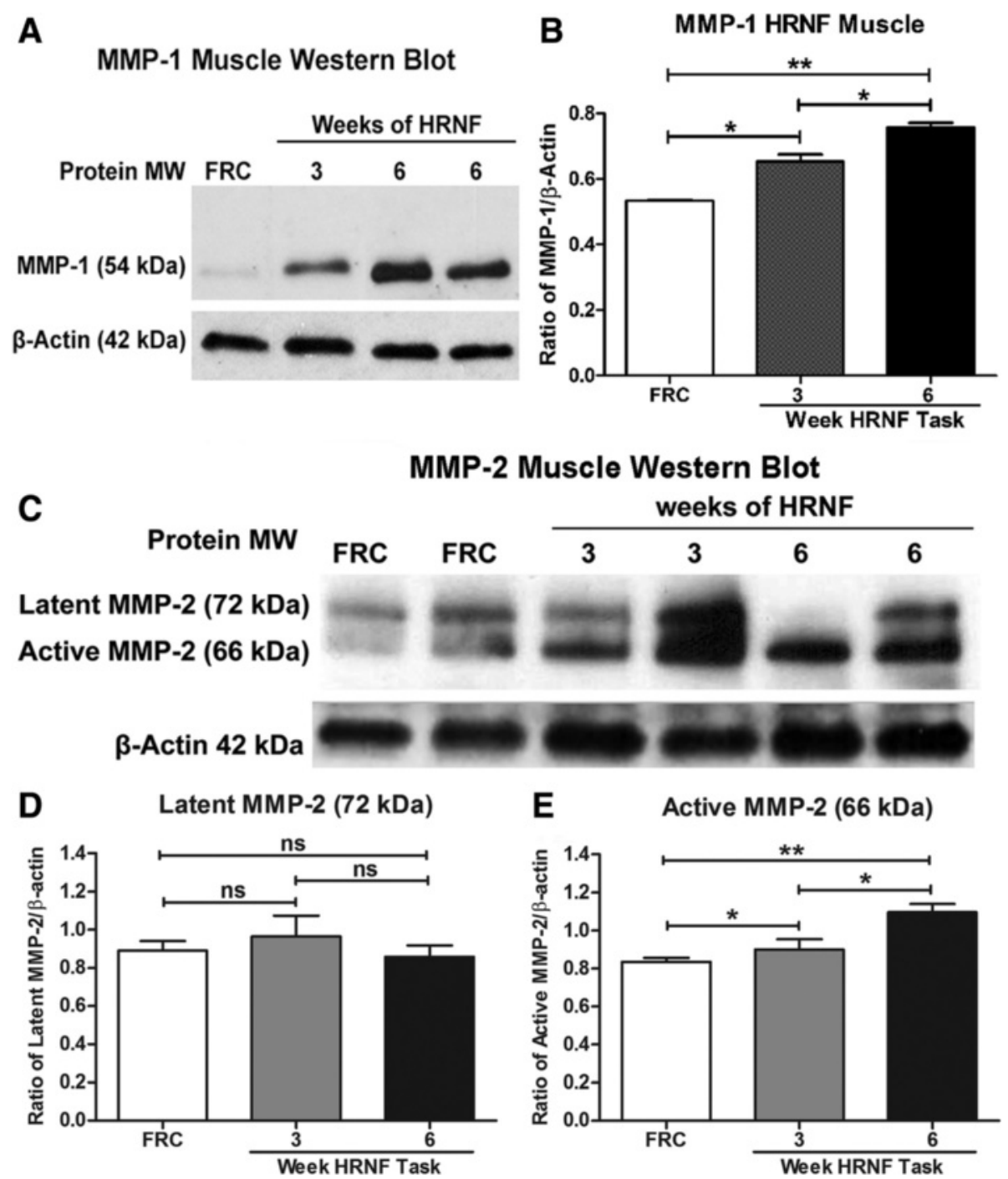

MMP-2 Muscle Western Blot
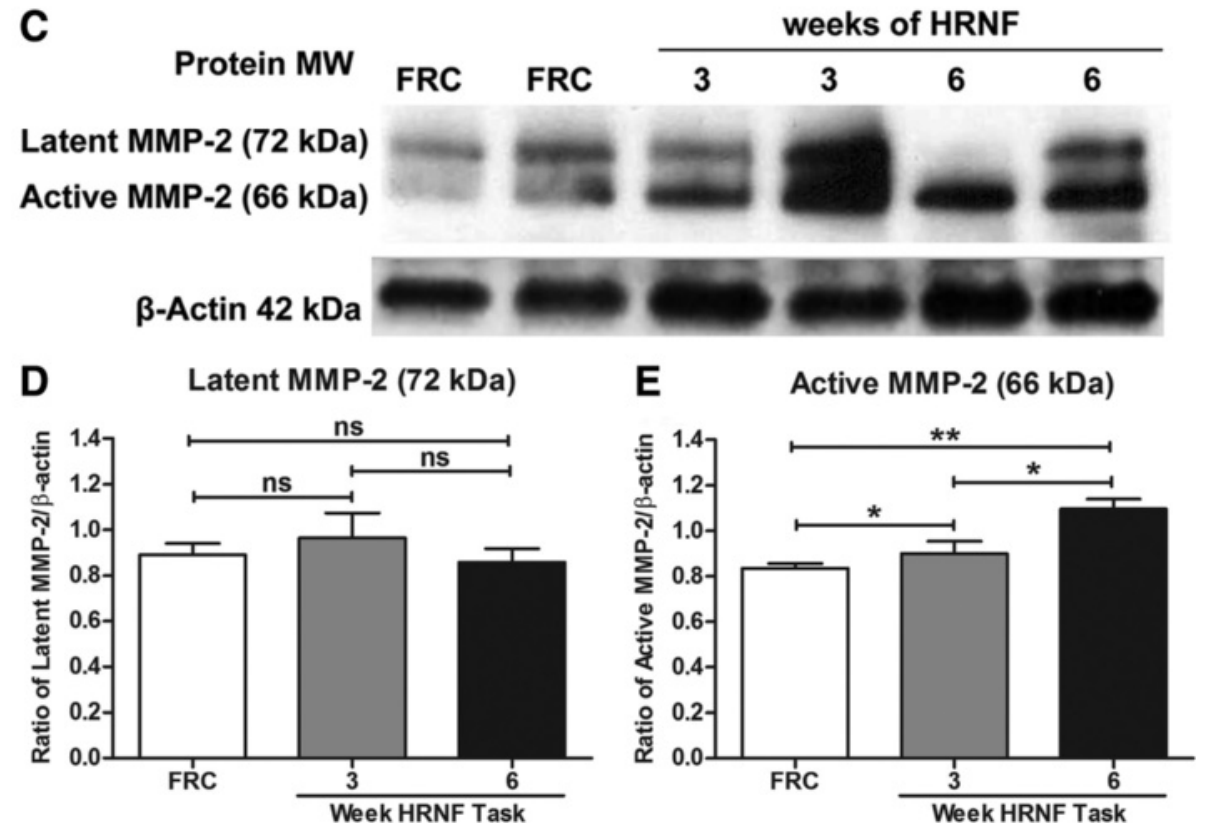

Fig. 2 Matrix metalloproteinase (MMP)-1 and -2 protein levels increase in flexor digitorum muscles with high repetition negligible force (HRNF) task. a Representative Western blot of muscle homogenates probed with anti-MMP-1. An immunoreactive band at the expected molecular weight of $54 \mathrm{kDa}$ was detected. $\beta$-actin was used as a loading control $(42 \mathrm{kDa})$. b Densitometric analysis of the MMP-1 band from three replicate Western blots were normalized to $\beta$-actin levels and documents significant increases relative to food restricted control (FRC) rats after 3 and 6 weeks of the HRNF task and between 3 and 6 weeks of the task. $\mathbf{c}$ Representative Western blot of muscle homogenates probed with anti-MMP-2. Bands are detected at the expected molecular weights for the latent $(72 \mathrm{kDa})$ and active $(66 \mathrm{kDa})$ forms. $\mathbf{d}$, e Densitometric analyses of the MMP-2 protein bands (72 and $66 \mathrm{kDa}$ ) from three replicate Western blots after normalization to $\beta$-actin levels show that only the active form is increased. ${ }^{*} p<0.05,{ }^{*} p<0.01$, compared to FRC rats; ns = not significant

0.05 each), particularly by 6 weeks of task performance. The $72 \mathrm{kDa}$ latent form of MMP-2 did not change significantly across groups (Fig. $2 \mathrm{c}$ and d). Expression levels of the active forms of MMP-3 (45 kDa and $28 \mathrm{kDa})$ also increased significantly in 6-week HRNF rats $(p<0.05$ each) compared to 3-week HRNF and FRC rat muscles (Fig. 3a, c and d). In contrast, the latent form of MMP-3 (57-59 kDa) did not change (Fig. 3a and c), and the level of active MMP-13 $(48 \mathrm{kDa})$ decreased with HRNF task performance $(p<$ 0.01) compared to controls (Fig. 3e and f).
HSP72 increases in muscles and Co-localizes with OA in sarcolemma of HRNF rats

ELISA analysis showed significant increased HSP72 protein in 6 -week HRNF muscles $(p<0.05)$ compared to controls (Fig. 4a). This result was supported by Western blot analysis that confirmed the expression and increase of the HSP72 protein in 6-wk HRNF rat muscles compared to controls (Fig 4b). We also evaluated the expression of OA and HSP72 using immunohistochemical methods. Little to no HSP72 or osteoactivin was observed in FRC rat muscles (representative examples 


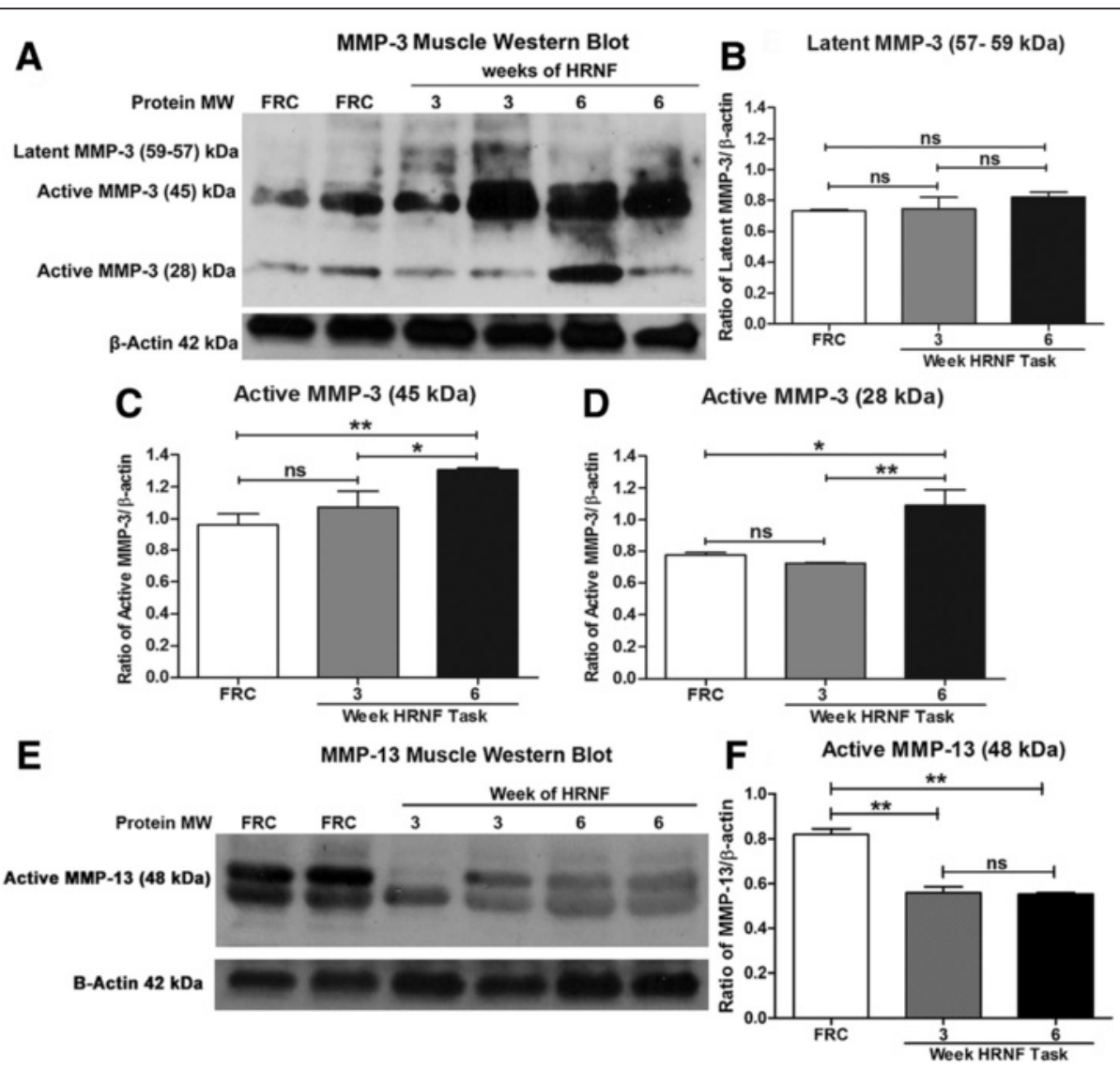

Fig. 3 Matrix metalloproteinase (MMP)-3 levels increase whereas MMP-13 decreases in flexor digitorum muscles with high repetition negligible force (HRNF) task. a Representative Western blot of muscle homogenates probed with MMP-3. Bands are at the expected molecular weights of latent and active forms of MMP-3 (approximately 57-59, 45, and $28 \mathrm{kDa}$ ). $\beta$-actin was used as a loading control. b-d Densitometric analysis of latent (57-59 kDa) and active (45 and $28 \mathrm{kDa}$ ) bands of MMP-3 from three replicate Western blots were normalized to $\beta$-actin levels. e A representative Western blot of muscle homogenates probed with MMP-13. Doublet bands observed at the expected molecular weight of active MMP-13 (approximately $48 \mathrm{kDa}$ ) were analyzed, averaged and normalized to the loading control. $\mathbf{f}$ Densitometric analysis of active (48 kDa) form of MMP-13 from three replicate Western blots after normalization to $\beta$-actin levels shows that it decreased significantly with the HRNF task. ${ }^{*} p<0.05$, ${ }^{* *} p<0.01$, compared to FRC rats; ns = not significant

shown in Fig. 4c and d). Double labeling immunohistochemistry in 6-week flexor digitorum muscles demonstrated increased expression of HSP72 (in red; Fig. 4e, g) and OA (in green; Fig. 4f, g), with co-localization in the sarcolemma surrounding the myofibers (Fig. 4g). Quantification of HSP72 immunostaining confirmed its increased immunoexpression in 6 week HRNF rat muscles compared to controls (Fig. 4h). No DAPI labeled cell bodies were visualized within the center of any of the myofibers at this 6-week HRNF time point (data not shown), indicating that the myofibers were not injured.

\section{Osteoactivin and HSP72 increase in tendons with HRNF} task

Next, we examined the expression of OA and HSP72 in flexor digitorum tendons. Western blot analysis showed that only the $47 \mathrm{kDa}$ form of $\mathrm{OA}$ was increased in tendons of 6 -week HRNF task performance $(p<0.01)$ compared to FRC rats (Fig. 5a and b). Immunoexpression of $\mathrm{OA}$ and its quantification showed significantly increased OA immunostaining in 6-week HRNF tendons $(p<0.05)$ compared to control rat tendons (Fig. 5c-f). OA was localized to tenocytes within 6-week HRNF tendons and to fibroblast- and macrophage-like cells located within the surrounding connective tissue (epitendon), but was absent in control tendons and epitendon (Fig. 5d-f ). Similarly, HSP72 immunostaining was significantly increased in tenocytes located within 6week HRNF tendons compared to controls (Fig. 5g-i).

\section{MMP-1 and -3 increase in tendons with HRNF task}

Western blot analysis showed the level of MMP-1 $(54 \mathrm{kDa})$ was increased in 6-week HRNF rat tendons $(p<0.05)$, compared to 3 -week HRNF and FRC rat 


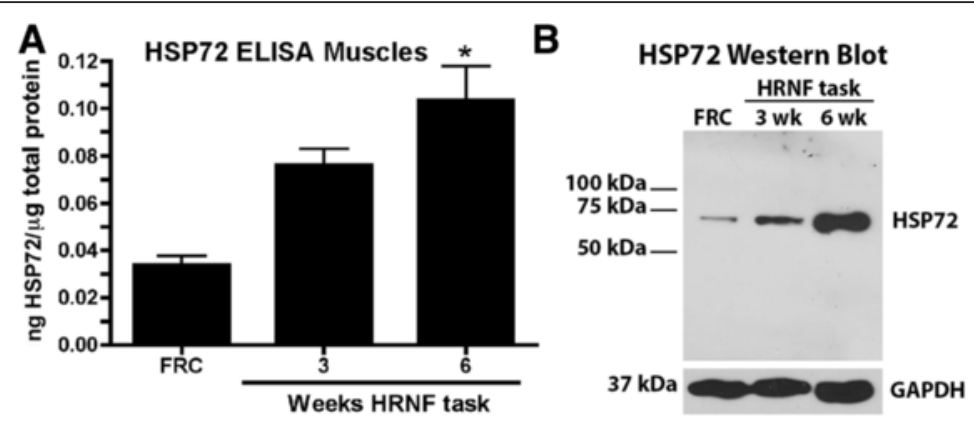

Osteoactivin and HSP72: Flexor digitorum longus muscle
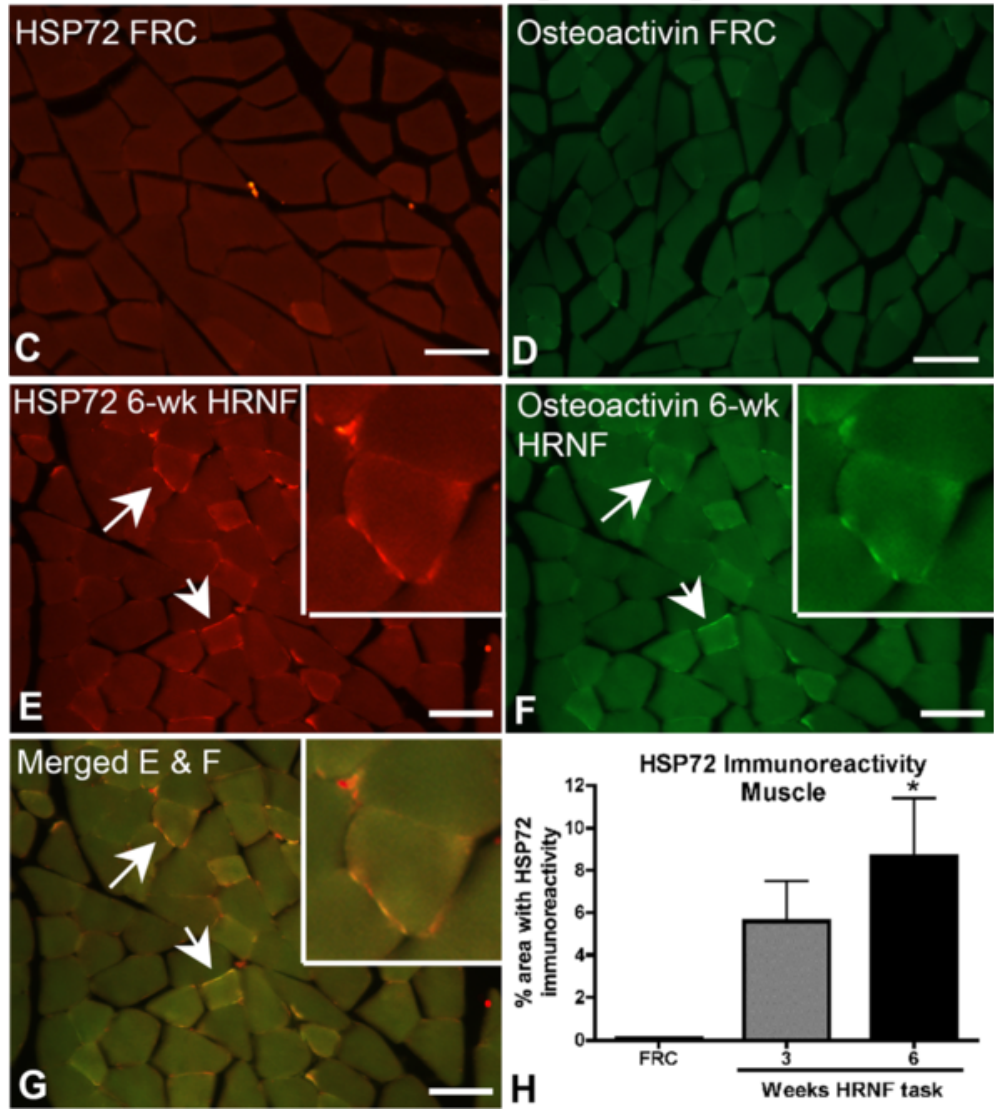

Fig. 4 Heat shock protein 72 (HSP72) increases in flexor digitorum muscles of high repetition negligible force (HRNF) rats and co-localizes with osteoactivin (OA) in the sarcolemma. a ELISA of HSP72 protein levels in FRC and HRNF rat muscle lysates. Nanograms of protein were normalized to $\mu \mathrm{g}$ of total protein. $\mathbf{b}$ Representative Western blots of muscle homogenates probed with anti-HSP72 were used to confirm that the molecular weight of the HSP protein recognized by the antibody was the inducible form of HSP72. c Immunostained image of HSP72 (red) in muscle from a food restricted control (FRC) rat (a proximal portion of the muscle was resected and cut transaxially and shown), showing that there was little to no immunostaining. $\mathbf{d}$ Immunostained images of OA (green) in muscle from a FRC rat (a proximal portion of the muscle was resected and cut transaxially and shown) showing little to no immunostaining. e-g Double-labeled immunostained images of HSP72 (red) and OA (green) were merged in muscle images from an 8-week HRNF rat (a proximal portion of the muscle was cut transaxially and is shown). Arrows indicate HSP72 and OA co-localization in myofiber sarcolemma. The insets in e-g show enlarged regions of these images to illustrate co-localization of HSP72 and OA in myofiber sarcolemma. $\mathbf{h}$ Quantification of HSP72-positive immunostaining as a percent of total tissue area. ${ }^{*} p<0.05$, compared to FRC rats. Scale bars in C-G $=50 \mu \mathrm{m}$

tendons (Fig. 6a and b). Note the variability of MMP1 in the 3-week HRNF tendons (Fig. 6a). This was a consistent finding. We next found that the latent $(57-59 \mathrm{kDa})$ and active $(45 \mathrm{kDa})$ forms of MMP-3 were increased significantly in 6-week HRNF rat tendons $(p<0.05)$ compared to 3-week HRNF and FRC rats (Fig. 6c-e). Variable expression of the latent forms of MMP-3 was observed in FRC and 3-week 


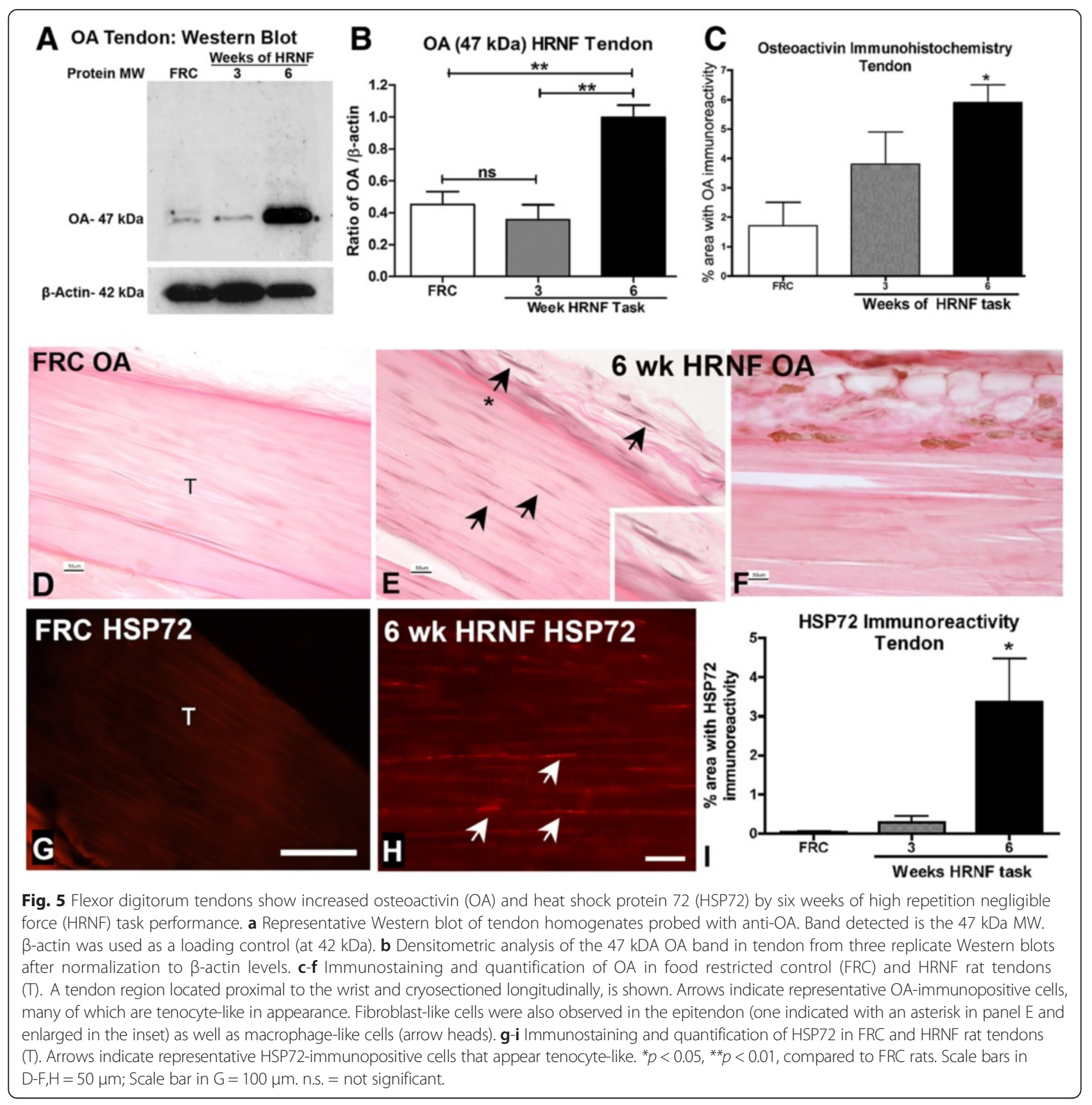

HRNF tendons, while the active form of MMP-3 (45 $\mathrm{kDa})$ was consistently increased in the 6-week HRNF tendons.

IL-1alpha and IL-1beta alter across time in muscles and tendons with HRNF Task

Lastly, we also observed transient yet significant increases of IL-1alpha in 3-week HRNF tendons (Fig. 7b) and IL-1beta in 3-week HRNF muscles (Fig. 7c). We also observed a very small but significant decrease in IL1alpha in 6-week HRNF muscles compared to controls (Fig 7a). No increase was observed for IL-1beta in tendons (Fig. 7d). TNF-alpha and IL-10 did not alter significantly with task performance in either tissue compared to controls (data not shown).

\section{Discussion}

For the first time to our knowledge, we show in a rat model of limb overuse that expression of the growth factor osteoactivin (OA) increases progressively in forearm muscles and tendons with prolonged performance of an upper extremity high repetition negligible force (HRNF) task for up to 6 weeks. Immunostaining also showed localization of OA to myofiber sarcolemma, 


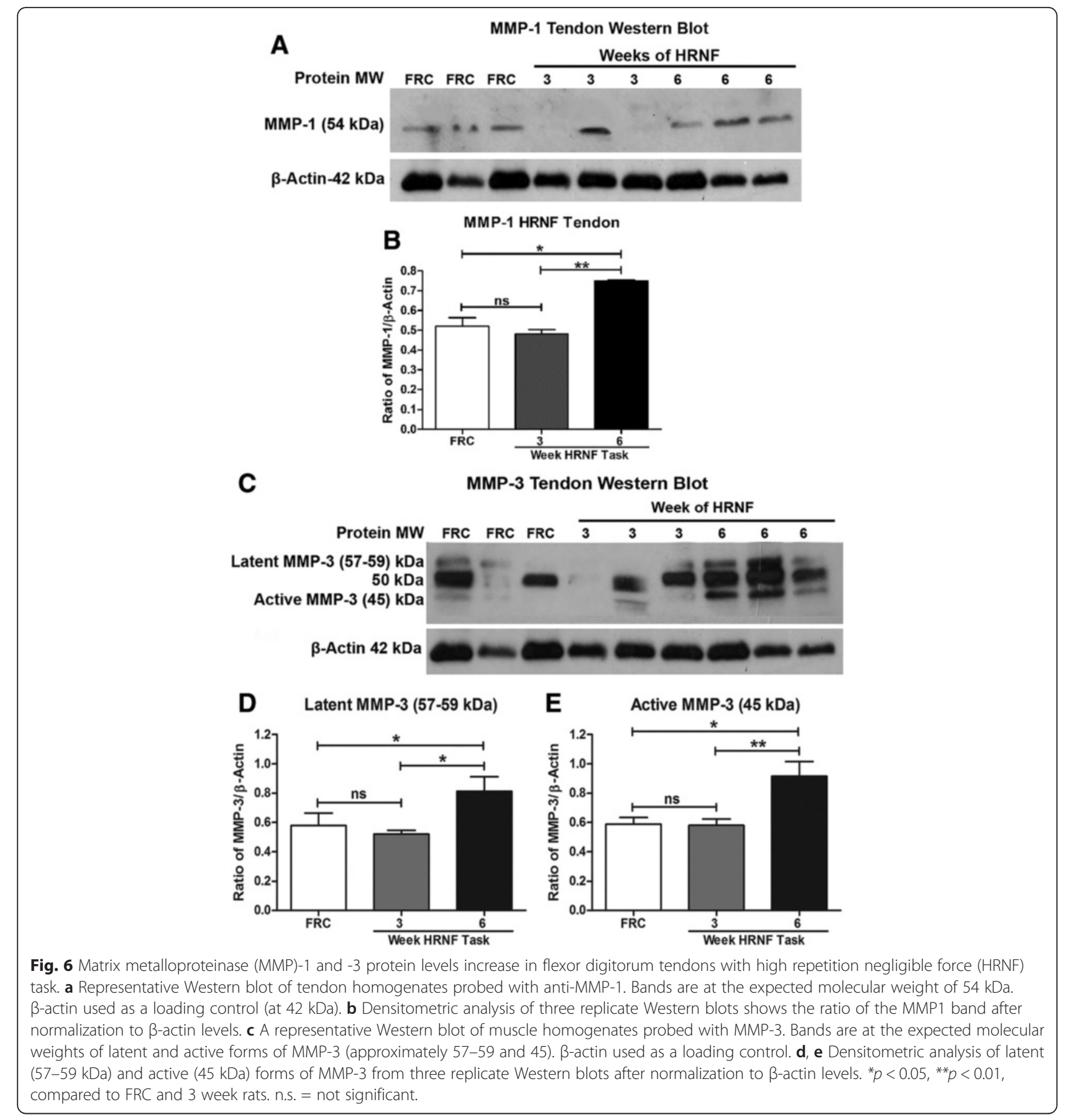

macrophage-like cells, fibroblast-like cells and tenocytes. Levels of enzymatic proteins related to tissue turnover, MMP-1, -2 and -3 , also progressively increased, whereas MMP-13 decreased, in forearm muscles with HRNF task performance. MMP-1 and -3 levels also progressively increased in forearm tendons. Levels of a known repair protein, HSP72, also increased only in 6-week HRNF muscles and tendons compared to controls, and co-localized with OA immunoexpression in the sarcolemma of 6-week HRNF muscles.
We have previously shown modest muscle and tendon injury, followed by a low-grade but transient inflammatory response, with performance of this HRNF reaching and food retrieval task $[9,35]$. Since inflammation occurring in injured tissues as a consequence of overuse is thought to be related to repair processes [40], we extended our past studies to examine repair and remodeling factors in this current study. Repair of musculoskeletal tissues may be driven by a number of anabolic factors. We examined OA because it has been identified 

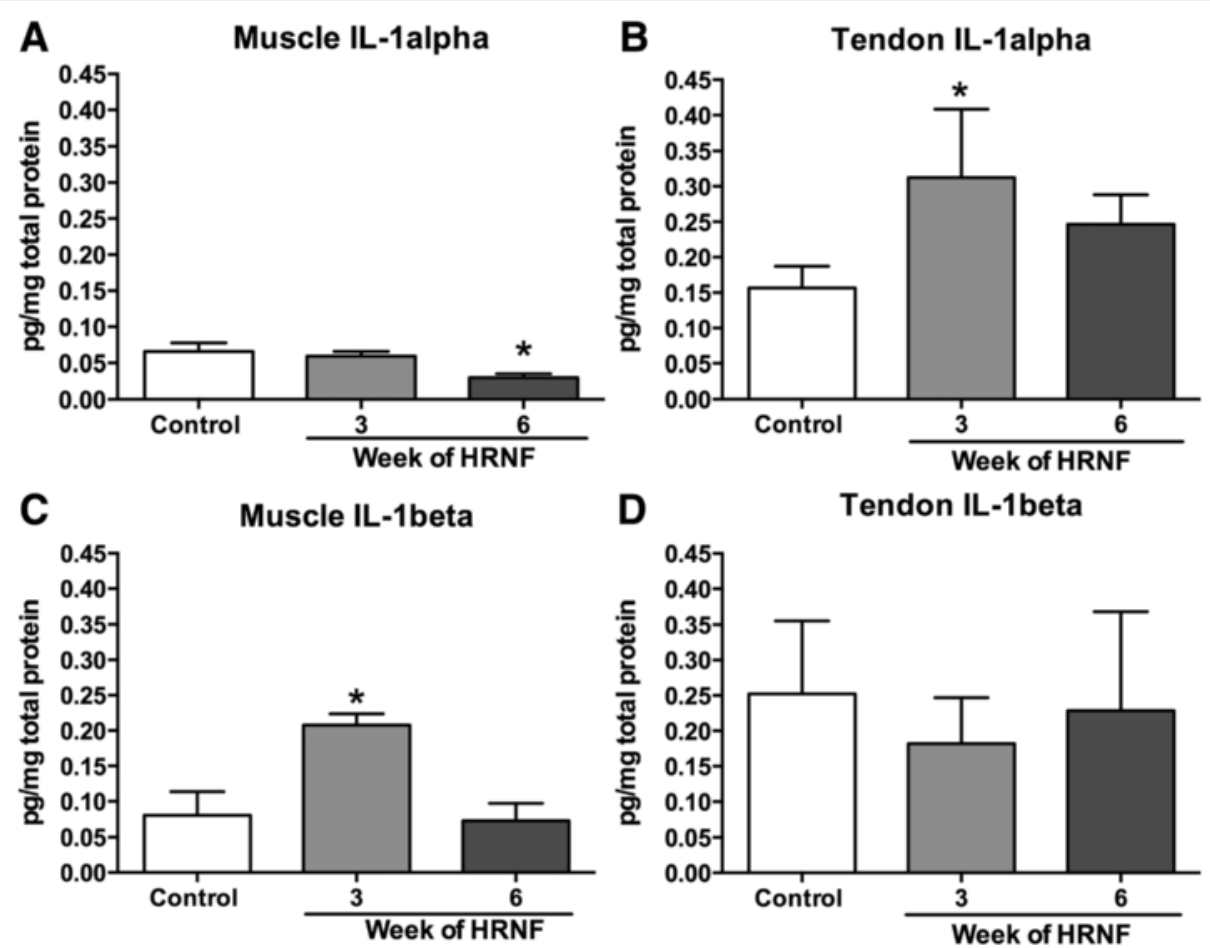

Fig. 7 ELISA of inflammatory cytokines in flexor digitorum muscles and tendons of reach limb. Data is shown for (a, b) interleukin (IL-1) alpha and (c, d) IL-1 beta in food restricted control (FRC) and 3- and 6-week HRNF rats. ${ }^{*} p<0.05$, compared to FRC rats

as an anabolic growth factor in long bones [41], and found that it was increased in muscles and tendons of HRNF rats, with the greatest increases in parallel with a return of inflammatory cytokines to baseline levels. The increase in $\mathrm{OA}$ was concomitant with increased MMP and HSP72, proteins known to participate in repair and remodeling processes, thus further supporting a role for $\mathrm{OA}$ as an anabolic molecule. Several studies have shown that OA regulates cell proliferation, adhesion, differentiation and synthesis of extracellular matrix proteins in various cell types under normal and repair/regeneration conditions [16, 41-49]. In skeletal muscle, OA increases after denervation or distraction injury $[14-16,50]$ and has been shown to up-regulate MMP-3 and -9 expression in fibroblasts infiltrating denervated skeletal muscle [16]. Extracellular fragments of OA produced by ectodomain shedding induce MMP-3 expression in myofibroblasts after unloading [14]. These latter responses serve to enhance tissue turnover and repair.

Tissue injury is known to induce the expression of matrix-related genes, including MMPs [51-54]. Therefore, we examined their expression and observed that performance of the HRNF task for 6 weeks increased MMP expression and found that MMP-1 (collagenase), -2 (gelatinase) and -3 (stromelysin-1) were increased in flexor digitorum muscles, while MMP-1 and -3 were increased in tendons. We have previously shown that MMP-2 increases in serum, forearm muscles and tendons of rats performing a high repetition low force lever-pulling task for 18 weeks [55]. MMPs are zinc-dependent proteases that regulate cell-matrix composition, modulate ECM turnover, and are produced by fibroblasts, mesenchymal cells and macrophages [56-59]. The expression of most MMPs is low in normal steady-state tissues and are induced only when ECM remodeling is needed [60], such as for musculoskeletal tissue adaptability to loading and training [61-63]. Their expression is transcriptionally controlled by growth factors, cell-cell and cell-matrix interactions [64-66] and inflammatory cytokines [62, 63]. Examination of an experimental model of muscle regeneration [cardiotoxin (CTX) injection] shows a tightly regulated time course of MMP activation and resolution of tissue damage [52, 67, 68]. Also, generalized MMP inhibition impairs muscle repair [69] further supporting their requirement in resolution of muscle damage [70].

In tendons, MMPs are involved in collagen catabolism and show increased activity with prolonged periods of high or low mechanical loading or during periods of tendon repair [71-73]. Studies have shown increased MMP-1 or MMP-2 with chronic loading of tendons [74] in tendons with signs of overuse injury $[75,76]$ and in flexor tendosynovial tissues collected from patients with carpal tunnel syndrome [77]. In agreement with our 
data, a synergistic effect of mechanical stretch and presence of inflammatory cytokines has been shown to induce MMP-1 and -3 expression in tendon cells more than stretch alone [78-80]. The increased MMPs with HRNF task performance are likely responding to the continued loading and transient increases of IL-1alpha in tendons and IL-1beta in muscles and are contributing to tissue remodeling for repair.

Since previous studies suggest that heat shock proteins (HSPs) play a role in skeletal muscle repair after highforce eccentric exercise and that elevated HSP70 and its inducible form (HSP72) protects skeletal muscle against further injury $[28,29]$, we examined its expression and found that this stress-inducible protein was increased in 6-week HRNF muscles compared to controls. HSP72 plays a role in skeletal muscle remodeling and adaptation processes in response to exercise and stress [81, 82]. Exercise training increases the expression of HSP72 a few days after the onset of training [83-85] while prolonged exercise training, using intermittent high-intensity treadmill running for 8 weeks, induces long-term enhancement of HSP70 expression in skeletal muscle [86]. Interestingly, Sjogaard et al. showed in human subjects that performance of repetitive tasks increased HSP72 in muscles while prolonged exercise training decreased its basal levels [87], suggestive of a clear difference between these two activities. Activation of HSP72 may play a dual role in inflammation [88], inhibiting the release of inflammatory cytokines including IL-1beta [89-93]. This interaction between HSP72 and inflammatory cytokines may explain our findings of only low levels of IL-1alpha and beta by 6 weeks of task performance.

As mentioned above, since HSP72 stimulate antiinflammatory cytokines and inhibit the release of some inflammatory cytokines, we next examined the muscles and tendons for presence of inflammatory cytokines. We observed that performance of a HRNF task for 3 weeks induces significant increases in IL-1alpha in tendons and IL-1beta in muscles, yet declines to baseline or even below baseline levels by 6 weeks of task performance. Since pro-inflammatory cytokine expression are induced at early time points during tissue repair [94], we suggest that the 3 week time point is the peak of inflammatory phase in this high repetition negligible force reaching and grasping model, and that the 6-week time point is the beginning of the repair proliferative phase, with HSP72 and OA mediating tissue repair and adaptation.

\section{Conclusions}

These findings suggest that performance of a high repetition negligible force reaching and grasping induces an inflammatory response at 3 weeks and then a repair response at 6 weeks that might be mediated, at least in part, by OA, MMPs and HSP72. Further research is needed to determine the production of these proteins in musculotendinous tissues undergoing higher levels of persistent overloading and tissue injury, such as in animals and humans performing a high repetition high force task for longer periods of time.

\section{Competing interests}

The authors declare that they have no competing interests.

\section{Authors' contributions}

MFB conceived of the study, directed its design and coordination, supervised the research, carried out data collection and statistical analysis, performed imaging, and drafted the manuscript. NF carried out immunoblotting studies, performed the statistical analysis, and co- drafted the manuscript. SA carried out the molecular genetic studies, and co-drafted the manuscript. MA carried out immunoassay studies. MT conceived of the HSP72 part of the study and helped to draft the manuscript. SP and FS provided key intellectual input and edited the paper. All authors read and approved the final manuscript.

\section{Acknowledgements}

The authors would like to thank Michele Harris for her aid in the operant behavioral training.

\section{Funding}

Research reported in this publication was supported by the National Institute of Arthritis and Musculoskeletal and Skin Diseases of the National Institutes of Health under Award Number AR056019 to MFB.

\section{Disclaimer}

The content is solely the responsibility of the authors and does not necessarily represent the official views of the National Institutes of Health.

\section{Author details}

${ }^{1}$ Department of Anatomy and Cell Biology, Temple University School of Medicine, Philadelphia, PA, USA. ${ }^{2}$ Department of Stem Cell Biology and Regenerative Medicine, Lerner Research Institute, Cleveland Clinic, Cleveland, $\mathrm{OH}$, USA. ${ }^{3}$ Department of Neurobiology and Anatomy, Wake Forest University School of Medicine, Winston-Salem, NC, USA. ${ }^{4}$ Department of Anatomy and Neurobiology, Northeast Ohio Medical University (NEOMED), Rootstown, $\mathrm{OH}$, USA.

Received: 9 April 2015 Accepted: 13 January 2016

Published online: 18 January 2016

\section{References}

1. Horton R. GBD 2010: understanding disease, injury, and risk. Lancet. 2012; 380(9859):2053-4. doi:10.1016/S0140-6736(12)62133-3.

2. Piligian $G$, Herbert $R$, Hearns $M$, Dropkin J, Landsbergis P, Cherniack M Evaluation and management of chronic work-related musculoskeletal disorders of the distal upper extremity. Am J Ind Med. 2000;37(1):75-93.

3. van Rijn RM, Huisstede BM, Koes BW, Burdorf A. Associations between workrelated factors and the carpal tunnel syndrome-a systematic review. Scand J Work Environ Health. 2009;35(1):19-36.

4. Gallagher S, Heberger JR. Examining the interaction of force and repetition on musculoskeletal disorder risk: a systematic literature review. Hum Factors. 2013;55(1):108-24.

5. Kannus $P$, Jozsa L, Natri A, Jarvinen M. Effects of training, immobilization and remobilization on tendons. Scand J Med Sci Sports. 1997;7(2):67-71.

6. Barr AE, Barbe MF. Pathophysiological tissue changes associated with repetitive movement: a review of the evidence. Phys Ther. 2002;82(2):173-87.

7. Cutlip RG, Hollander MS, Johnson GA, Johnson BW, Friend SA, Baker BA. Magnetic resonance imaging of graded skeletal muscle injury in live rats. Environ Health Insights. 2014;8 Suppl 1:31-9. doi:10.4137/EHI.S15255.

8. Barbe MF, Barr AE. Inflammation and the pathophysiology of work-related musculoskeletal disorders. Brain Behav Immun. 2006;20(5):423-9. doi:10.1016/j.bbi.2006.03.001.

9. Barbe MF, Barr AE, Gorzelany I, Amin M, Gaughan JP, Safadi FF. Chronic repetitive reaching and grasping results in decreased motor performance and widespread tissue responses in a rat model of MSD. J Orthop Res. 2003; 21(1):167-76. doi:10.1016/S0736-0266(02)00086-4. 
10. Abdelmagid SM, Barr AE, Rico M, Amin M, Litvin J, Popoff SN, et al. Performance of repetitive tasks induces decreased grip strength and increased fibrogenic proteins in skeletal muscle: role of force and inflammation. PLoS ONE. 2012;7(5):e38359. doi:10.1371/journal.pone.0038359.

11. Barr AE, Barbe MF, Clark BD. Systemic inflammatory mediators contribute to widespread effects in work-related musculoskeletal disorders. Exerc Sport Sci Rev. 2004;32(4):135-42.

12. Cutlip RG, Baker BA, Hollander M, Ensey J. Injury and adaptive mechanisms in skeletal muscle. J Electromyogr Kinesiol. 2009;19(3):358-72. doi:10.1016/j. jelekin.2008.06.007.

13. Abdelmagid SM, Barbe MF, Hadjiargyrou M, Owen TA, Razmpour R, Rehman $\mathrm{S}$, et al. Temporal and spatial expression of osteoactivin during fracture repair. J Cell Biochem. 2010;111(2):295-309. doi:10.1002/jcb.22702.

14. Furochi H, Tamura S, Mameoka M, Yamada C, Ogawa T, Hirasaka K, et al. Osteoactivin fragments produced by ectodomain shedding induce MMP-3 expression via ERK pathway in mouse NIH-3T3 fibroblasts. FEBS Lett. 2007; 581(30):5743-50. doi:10.1016/j.febslet.2007.11.036.

15. Furochi H, Tamura S, Takeshima K, Hirasaka K, Nakao R, Kishi K, et al. Overexpression of osteoactivin protects skeletal muscle from severe degeneration caused by long-term denervation in mice. J Medlnvest. 2007;54(3-4):248-54.

16. Ogawa T, Nikawa T, Furochi H, Kosyoji M, Hirasaka K, Suzue N, et al. Osteoactivin upregulates expression of MMP-3 and MMP-9 in fibroblasts infiltrated into denervated skeletal muscle in mice. Am J Physiol. 2005; 289(3):(697-707

17. Shikano S, Bonkobara M, Zukas PK, Ariizumi K. Molecular Cloning of a Dendritic Cell-associated Transmembrane Protein, DC-HIL, That Promotes RGD-dependent Adhesion of Endothelial Cells through Recognition of Heparan Sulfate Proteoglycans. J Biol Chem. 2001;276(11):8125-34.

18. Psarras S, Mavroidis M, Sanoudou D, Davos CH, Xanthou G, Varela AE, et al. Regulation of adverse remodelling by osteopontin in a genetic heart failure model. Eur Heart J. 2012;33(15):1954-63. doi:10.1093/eurheartj/ehr119.

19. Hoashi T, Sato S, Yamaguchi Y, Passeron T, Tamaki K, Hearing VJ. Glycoprotein nonmetastatic melanoma protein b, a melanocytic cell marker, is a melanosome-specific and proteolytically released protein. FASEB J. 2010; 24(5):1616-29. doi:10.1096/fj.09-151019.

20. Rose AA, Annis MG, Dong Z, Pepin F, Hallett M, Park M, et al. ADAM10 releases a soluble form of the GPNMB/Osteoactivin extracellular domain with angiogenic properties. PLOS ONE. 2010;5(8):e12093. doi:10.1371/journal. pone.0012093

21. Qian X, Mills E, Torgov M, LaRochelle WJ, Jeffers M. Pharmacologically enhanced expression of GPNMB increases the sensitivity of melanoma cells to the CR011-vCMMAE antibody-drug conjugate. Mol Oncol. 2008;2(1):8193. doi:10.1016/j.molonc.2008.02.002.

22. Gehrig SM, van der Poel C, Sayer TA, Schertzer JD, Henstridge DC, Church JE, et al. Hsp72 preserves muscle function and slows progression of severe muscular dystrophy. Nature. 2012;484(7394):394-8. doi:10.1038/nature10980.

23. Miyabara EH, Martin JL, Griffin TM, Moriscot AS, Mestril R. Overexpression of inducible 70-kDa heat shock protein in mouse attenuates skeletal muscle damage induced by cryolesioning. Am J Physiol. 2006;290(4):C1128-38. doi:10.1152/ajpcell.00399.2005.

24. Miyabara EH, Nascimento TL, Rodriques DC, Moriscot AS, Davila WF, AitMou $Y$, et al. Overexpression of inducible 70-kDa heat shock protein in mouse improves structural and functional recovery of skeletal muscles from atrophy. Pflugers Arch - Eur J Physiol. 2012;463(5):733-41. doi:10.1007/ s00424-012-1087-x

25. Senf SM, Dodd SL, McClung JM, Judge AR. Hsp70 overexpression inhibits NF-kappaB and Foxo3a transcriptional activities and prevents skeletal muscle atrophy. FASEB J. 2008;22(11):3836-45. doi:10.1096/fj.08-110163.

26. Parsell DA, Lindquist $S$. The function of heat-shock proteins in stress tolerance: degradation and reactivation of damaged proteins. Annu Rev Genet. 1993;27:437-96. doi:10.1146/annurev.ge.27.120193.002253.

27. Koh TJ. Do small heat shock proteins protect skeletal muscle from injury? Exerc Sport Sci Rev. 2002;30(3):117-21

28. McArdle A, Dillmann WH, Mestril R, Faulkner JA, Jackson MJ. Overexpression of HSP70 in mouse skeletal muscle protects against muscle damage and agerelated muscle dysfunction. FASEB J. 2004;18(2):355-7. doi:10.1096/fj.03-0395fje.

29. Paulsen G, Vissing K, Kalhovde JM, Ugelstad I, Bayer ML, Kadi F, et al. Maximal eccentric exercise induces a rapid accumulation of small heat shock proteins on myofibrils and a delayed HSP70 response in humans. Am J Physiol Regul Integr Comp Physiol. 2007;293(2):R844-53. doi:10.1152/ ajpregu.00677.2006.
30. Carmeli E, Beiker R, Maor M, Kodesh E. Increased iNOS, MMP-2, and HSP-72 in skeletal muscle following high-intensity exercise training. J Basic Clin Physiol Pharmacol. 2010;21(2):127-46.

31. Hirunsai M, Srikuea R, Yimlamai T. Heat stress promotes extracellular matrix remodelling via TGF-beta1 and MMP-2/TIMP-2 modulation in tenotomised soleus and plantaris muscles. Int J Hyperthermia. 2015:1-13. doi:10.3109/ 02656736.2014.1002019.

32. Senf SM, Howard TM, Ahn B, Ferreira LF, Judge AR. Loss of the inducible hsp70 delays the inflammatory response to skeletal muscle injury and severely impairs muscle regeneration. PLoS ONE. 2013;8(4):e62687. doi:10.1371/journal.pone.0062687.

33. Silverstein BA, Fine $\sqcup$, Armstrong TJ. Hand wrist cumulative trauma disorders in industry. Br J Ind Med. 1986;43(11):779-84.

34. Bertelli JA, Mira JC. The grasping test: a simple behavioral method for objective quantitative assessment of peripheral nerve regeneration in the rat. J Neurosci Methods. 1995;58(1-2):151-5

35. Barbe MF, Elliott MB, Abdelmagid SM, Amin M, Popoff SN, Safadi FF, et al. Serum and tissue cytokines and chemokines increase with repetitive upper extremity tasks. J Orthop Res. 2008;26(10):1320-6. doi:10.1002/jor.20674.

36. Rani S, Barbe MF, Barr AE, Litivn J. Role of TNF alpha and PLF in bone remodeling in a rat model of repetitive reaching and grasping. J Cell Physiol. 2010;225(1):152-67. doi:10.1002/jcp.22208.

37. Abdelmagid SM, Barbe MF, Arango-Hisijara I, Owen TA, Popoff SN, Safadi FF. Osteoactivin acts as downstream mediator of BMP-2 effects on osteoblast function. J Cell Physiol. 2007;210(1):26-37. doi:10.1002/jcp.20841.

38. Fedorczyk JM, Barr AE, Rani S, Gao HG, Amin M, Amin S, et al. Exposuredependent increases in IL-1beta, substance P, CTGF, and tendinosis in flexor digitorum tendons with upper extremity repetitive strain injury. J Orthop Res. 2010;28(3):298-307. doi:10.1002/jor.20984

39. Al-Shatti T, Barr AE, Safadi FF, Amin M, Barbe MF. Increase in inflammatory cytokines in median nerves in a rat model of repetitive motion injury. J Neuroimmunol. 2005;167(1-2):13-22. doi:10.1016/j.jneuroim.2005.06.013.

40. Song YF, Forsgren S, Yu JG, Lorentzon R, Stal PS. Effects on Contralatera Muscles after Unilateral Electrical Muscle Stimulation and Exercise. PLoS ONE. 2012;7(12):e52230. doi:10.1371/journal.pone.0052230.

41. Safadi FF, Xu J, Smock SL, Rico MC, Owen TA, Popoff SN. Cloning and characterization of osteoactivin, a novel cDNA expressed in osteoblasts. J Cell Biochem. 2001:84(1):12-26.

42. Abdelmagid SM, Barbe MF, Rico MC, Salihoglu S, Arango-Hisijara I, Selim $\mathrm{AH}$, et al. Osteoactivin, an anabolic factor that regulates osteoblast differentiation and function. Exp Cell Res. 2008;314(13):2334-51. doi:10.1016/j.yexcr.2008.02.006.

43. Abe H, Uto H, Takami Y, Takahama Y, Hasuike S, Kodama M, et al. Transgenic expression of osteoactivin in the liver attenuates hepatic fibrosis in rats. Biochem Biophys Res Commun. 2007;356(3):610-5. doi:10.1016/j.bbrc.2007.03.035.

44. Chung JS, Sato K, Dougherty II, Cruz Jr PD, Ariizumi K. DC-HIL is a negative regulator of T lymphocyte activation. Blood. 2007;109(10):4320-7.

45. Haralanova-llieva B, Ramadori G, Armbrust T. Expression of osteoactivin in rat and human liver and isolated rat liver cells. J Hepatol. 2005;42(4):565-72. doi:10.1016/j.jhep.2004.12.021.

46. Nakamura A, Ishii A, Ohata C, Komurasaki T. Early induction of osteoactivin expression in rat renal tubular epithelial cells after unilateral ureteral obstruction. Exp Toxicol Pathol. 2007;59(1):53-9.

47. Onaga M, Ido A, Hasuike S, Uto H, Moriuchi A, Nagata K, et al. Osteoactivin expressed during cirrhosis development in rats fed a choline-deficient, L-amino acid-defined diet, accelerates motility of hepatoma cells. J Hepatol. 2003;39(5):779-85.

48. Rich JN, Shi Q, Hjelmeland M, Cummings TJ, Kuan CT, Bigner DD, et al. Bone-related genes expressed in advanced malignancies induce invasion and metastasis in a genetically defined human cancer model. J Biol Chem. 2003:278(18):15951-7. doi:10.1074/jbc.M211498200.

49. Frara N, Abdelmagid SM, Sondag GR, Moussa FM, Yingling VR, Owen TA et al. Transgenic Expression of Osteoactivin/gpnmb Enhances Bone Formation In Vivo and Osteoprogenitor Differentiation Ex Vivo. J Cell Physiol. 2016 Jan;231(1):72-83. doi:10.1002/jcp.25020.

50. Tonogai I, Takahashi M, Yukata K, Sato R, Nikawa T, Yasui N, et al. Osteoactivin attenuates skeletal muscle fibrosis after distraction osteogenesis by promoting extracellular matrix degradation/remodeling. I Pediatr Orthop B. 2015:24(2):162-9. doi:10.1097/BPB.0000000000000117.

51. Kherif S, Dehaupas M, Lafuma C, Fardeau M, Alameddine HS. Matrix metalloproteinases MMP-2 and MMP-9 in denervated muscle and injured nerve. Neuropathol Appl Neurobiol. 1998;24(4):309-19. 
52. Kherif S, Lafuma C, Dehaupas M, Lachkar S, Fournier JG, Verdiere-Sahuque M, et al. Expression of matrix metalloproteinases 2 and 9 in regenerating skeletal muscle: a study in experimentally injured and mdx muscles. Dev Biol. 1999;205(1):158-70. doi:10.1006/dbio.1998.9107.

53. Urso ML, Szelenyi ER, Warren GL, Barnes BR. Matrix metalloprotease-3 and tissue inhibitor of metalloprotease-1 mRNA and protein levels are altered in response to traumatic skeletal muscle injury. Eur J Appl Physiol. 2010;109(5): 963-72. doi:10.1007/s00421-010-1435-5.

54. Guerin CW, Holland PC. Synthesis and secretion of matrix-degrading metalloproteases by human skeletal muscle satellite cells. Dev Dyn. 1995; 202(1):91-9. doi:10.1002/aja.1002020109.

55. Gao HG, Fisher PW, Lambi AG, Wade CK, Barr-Gillespie AE, Popoff SN, et al. Increased Serum and Musculotendinous Fibrogenic Proteins following Persistent Low-Grade Inflammation in a Rat Model of Long-Term Upper Extremity Overuse. PLOS ONE. 2013;8(8):e71875. doi:10.1371/journal.pone.0071875.

56. Mandal M, Mandal A, Das S, Chakraborti T, Chakraborti S. Identification, purification and partial characterization of tissue inhibitor of matrix metalloproteinase-2 in bovine pulmonary artery smooth muscle. Mol Cell Biochem. 2003:254(1-2):275-87.

57. Massova I, Kotra LP, Fridman R, Mobashery S. Matrix metalloproteinases: structures, evolution, and diversification. FASEB J. 1998:12(12):1075-95.

58. Visse R, Nagase H. Matrix metalloproteinases and tissue inhibitors of metalloproteinases: structure, function, and biochemistry. Circ Res. 2003; 92(8):827-39. doi:10.1161/01.RES.0000070112.80711.3D.

59. Woessner Jr JF. Matrix metalloproteinases and their inhibitors in connective tissue remodeling. FASEB J. 1991;5(8):2145-54

60. Nagase $H$, Visse R, Murphy G. Structure and function of matrix metalloproteinases and TIMPs. Cardiovasc Res. 2006;69(3):562-73. doi:10.1016/j.cardiores.2005.12.002.

61. Kjaer M. Role of extracellular matrix in adaptation of tendon and skeletal muscle to mechanical loading. Physiol Rev. 2004;84(2):649-98. doi:10.1152/ physrev.00031.2003.

62. Cawston TE. Proteinases and inhibitors. Br Med Bull. 1995;51(2):385-401.

63. Murphy G, Willenbrock F, Crabbe T, O'Shea M, Ward R, Atkinson S, et al. Regulation of matrix metalloproteinase activity. Ann N Y Acad Sci. 1994;732:31-41.

64. Delany AM, Brinckerhoff CE. Post-transcriptional regulation of collagenase and stromelysin gene expression by epidermal growth factor and dexamethasone in cultured human fibroblasts. J Cell Biochem. 1992;50(4): 400-10. doi:10.1002/jcb.240500409.

65. Nagase H, Woessner Jr JF. Matrix metalloproteinases. J Biol Chem. 1999; 274(31):21491-4

66. Overall $\mathrm{CM}$, Wrana JL, Sodek J. Transcriptional and post-transcriptional regulation of $72-k D a$ gelatinase/type IV collagenase by transforming growth factor-beta 1 in human fibroblasts. Comparisons with collagenase and tissue inhibitor of matrix metalloproteinase gene expression. J Biol Chem. 1991; 266(21):14064-71.

67. Goetsch SC, Hawke TJ, Gallardo TD, Richardson JA, Garry DJ. Transcriptional profiling and regulation of the extracellular matrix during muscle regeneration. Physiol Genomics. 2003;14(3):261-71. doi:10.1152/ physiolgenomics.00056.2003

68. Zimowska M, Brzoska E, Swierczynska M, Streminska W, Moraczewski J. Distinct patterns of MMP-9 and MMP-2 activity in slow and fast twitch skeletal muscle regeneration in vivo. Int J Dev Biol. 2008;52(2-3):307-14. doi:10.1387/ijdb.072331mz.

69. Bellayr I, Holden K, Mu X, Pan H, Li Y. Matrix metalloproteinase inhibition negatively affects muscle stem cell behavior. Int J Clin Exp Pathol. 2013;6(2):124-41.

70. Lei HQ, Leong D, Smith LR, Barton ER. Matrix metalloproteinase 13 is a new contributor to skeletal muscle regeneration and critical for myoblast migration. Am J Physiol-Cell Ph. 2013;305(5):C529-C38. doi:10.1152/ajpcell.00051.2013.

71. De Mello Malheiro OC, Giacomini CT, Justulin Jr LA, Delella FK, Dal-Pai-Silva M, Felisbino SL. Calcaneal tendon regions exhibit different MMP-2 activation after vertical jumping and treadmill running. Anat Rec (Hoboken). 2009; 292(10):1656-62. doi:10.1002/ar.20953.

72. Kamekura S, Hoshi K, Shimoaka T, Chung U, Chikuda H, Yamada T, et al. Osteoarthritis development in novel experimental mouse models induced by knee joint instability. Osteoarthr Cartil / OARS, Osteoarthritis Research Society. 2005;13(7):632-41. doi:10.1016/j.joca.2005.03.004.

73. Pap G, Eberhardt R, Sturmer I, Machner A, Schwarzberg H, Roessner A, et al. Development of osteoarthritis in the knee joints of Wistar rats after strenuous running exercise in a running wheel by intracranial self-stimulation. Pathol Res Pract. 1998;194(1):41-7. doi:10.1016/S0344-0338(98)80010-1.
74. Asundi KR, Rempel DM. MMP-1, IL-1 beta, and COX-2 mRNA expression is modulated by static load in rabbit flexor tendons. Ann Biomed Eng. 2008; 36(2):237-43. doi:10.1007/s10439-007-9427-2.

75. Fu SC, Chan BP, Wang W, Pau HM, Chan KM, Rolf CG. Increased expression of matrix metalloproteinase 1 (MMP1) in 11 patients with patellar tendinosis. Acta Orthop Scand. 2002;73(6):658-62. doi:10.1080/ 000164702321039624

76. Riley G. The pathogenesis of tendinopathy. A molecular perspective. Rheumatology. 2004;43(2):131-42. doi:10.1093/rheumatology/keg448.

77. Hirata H, Tsujii M, Yoshida T, Imanaka-Yoshida K, Morita A, Okuyama N, et al. MMP-2 expression is associated with rapidly proliferative arteriosclerosis in the flexor tenosynovium and pain severity in carpal tunnel syndrome. J Pathol. 2005;205(4):443-50. doi:10.1002/path.1709.

78. Kawai Y, Matsumoto Y, Watanabe K, Yamamoto H, Satoh K, Murata M, et al. Hemodynamic forces modulate the effects of cytokines on fibrinolytic activity of endothelial cells. Blood. 1996;87(6):2314-21.

79. Ngan P, Saito S, Saito M, Lanese R, Shanfeld J, Davidovitch Z. The interactive effects of mechanical stress and interleukin-1 beta on prostaglandin $E$ and cyclic AMP production in human periodontal ligament fibroblasts in vitro: comparison with cloned osteoblastic cells of mouse (MC3T3-E1). Arch Oral Biol. 1990;35(9):717-25

80. Archambault J, Tsuzaki M, Herzog W, Banes AJ. Stretch and interleukin-1beta induce matrix metalloproteinases in rabbit tendon cells in vitro. J Orthop Res. 2002;20(1):36-9. doi:10.1016/S0736-0266(01)00075-4.

81. Goto K, Honda M, Kobayashi T, Uehara K, Kojima A, Akema T, et al. Heat stress facilitates the recovery of atrophied soleus muscle in rat. Jpn J Physiol. 2004;54(3):285-93.

82. Naito H, Powers SK, Demirel HA, Sugiura T, Dodd SL, Aoki J. Heat stress attenuates skeletal muscle atrophy in hindlimb-unweighted rats. J Appl Physiol (1985). 2000;88(1):359-63.

83. Locke M, Tanguay RM, Klabunde RE, lanuzzo CD. Enhanced postischemic myocardial recovery following exercise induction of HSP 72. Am J Physiol. 1995:269(1 Pt 2):H320-5.

84. Noble EG, Moraska A, Mazzeo RS, Roth DA, Olsson MC, Moore RL, et al. Differential expression of stress proteins in rat myocardium after free wheel or treadmill run training. J Appl Physiol (1985). 1999;86(5):1696-701.

85. Paroo Z, Haist JV, Karmazyn M, Noble EG. Exercise improves postischemic cardiac function in males but not females: consequences of a novel sexspecific heat shock protein 70 response. Circ Res. 2002;90(8):911-7.

86. Ogata T, Oishi Y, Higashida K, Higuchi M, Muraoka I. Prolonged exercise training induces long-term enhancement of HSP70 expression in rat plantaris muscle. Am J Physiol Regul Integr Comp Physiol. 2009;296(5): R1557-63. doi:10.1152/ajpregu.90911.2008.

87. Sjogaard G, Zebis MK, Kiilerich K, Saltin B, Pilegaard H. Exercise training and work task induced metabolic and stress-related mRNA and protein responses in myalgic muscles. BioMed Res Int. 2013;2013:984523. doi:10.1155/2013/984523.

88. Noble EG, Shen GX. Impact of exercise and metabolic disorders on heat shock proteins and vascular inflammation. Autoimmune Dis. 2012;2012: 836519. doi:10.1155/2012/836519.

89. De AK, Kodys KM, Yeh BS, Miller-Graziano C. Exaggerated human monocyte IL-10 concomitant to minimal TNF-alpha induction by heat-shock protein 27 (Hsp27) suggests Hsp27 is primarily an antiinflammatory stimulus. J Immunol. 2000;165(7):3951-8.

90. Wieten L, Broere F, van der Zee R, Koerkamp EK, Wagenaar J, van Eden W. Cell stress induced HSP are targets of regulatory T cells: a role for HSP inducing compounds as anti-inflammatory immuno-modulators? FEBS Lett. 2007;581(19):3716-22. doi:10.1016/j.febslet.2007.04.082.

91. Cahill CM, Waterman WR, Xie Y, Auron PE, Calderwood SK. Transcriptional repression of the prointerleukin 1 beta gene by heat shock factor 1. J Biol Chem. 1996:271(40):24874-9.

92. Kim HP, Wang X, Zhang J, Suh GY, Benjamin IJ, Ryter SW, et al. Heat shock protein-70 mediates the cytoprotective effect of carbon monoxide: involvement of p38 beta MAPK and heat shock factor-1. J Immunol. 2005;175(4):2622-9.

93. Pockley AG, Calderwood SK, Multhoff G. The atheroprotective properties of Hsp70: a role for Hsp70-endothelial interactions? Cell Stress Chaperones. 2009;14(6):545-53. doi:10.1007/s12192-009-0113-1.

94. Karlmark KR, Zimmermann HW, Roderburg C, Gassler N, Wasmuth HE, Luedde $T$, et al. The fractalkine receptor CX(3)CR1 protects against liver fibrosis by controlling differentiation and survival of infiltrating hepatic monocytes. Hepatology. 2010;52(5):1769-82. doi:10.1002/hep.23894. 